\section{INDUCED CIRCULARITY FOR SELECTIVE WORKERS. THE CASE OF SEASONAL LABOR MOBILITY SCHEMES IN THE SPANISH AGRICULTURE}

Ana López-Sala

Consejo Superior de Investigaciones Científicas ana.Isala@cchs.csic.es

Cómo citar este artículo/Citation: López-Sala, A. (2016). "Induced circularity for selective workers. The case of seasonal labor mobility schemes in the Spanish agriculture". Arbor, 192 (777): a287. doi: http://dx.doi.org/10.3989/ arbor.2016.777n1003

Received: September 12th, 2013. Accepted: October 31st, 2014.

ABSTRACT: At the end of the 1990s Spain began to design programs directed at recruiting seasonal workers for the agriculture sector. During the past decade, coinciding with a period of intense economic growth, these programs were applied in certain Spanish provinces with the objective of promoting forms of temporary and circular migration. The implementation of these programs, in which a broad number of public and private actors participated, was an exception to the traditionally reactive Spanish policy on labor immigration. In addition, these programs gave seasonal migrant workers an anomalous legal status by blocking them from obtaining permanent residence permits and limiting their right to settle in Spain. This article analyzes the design and implementation of these programs in Spain, the involvement of various actors, and the way they were managed in two provinces where they had the greatest volume and continuity, Huelva, in region of Andalusia and Lleida in Catalonia.

KEYWORDS: Seasonal migrant workers programs; induced circular migration; labor migration; agriculture; Spain.

\section{CIRCULARIDAD INDUCIDA DE TRABAJADORES SELECCIONADOS. EL CASO DE LOS ESQUEMAS DE MOVILIDAD LABORAL ESTACIONAL EN LA AGRICULTURA ESPAÑOLA}

Copyright: $@ 2016$ CSIC. This is an open-access article distributed under the terms of the Creative Commons Attribution-Non Commercial (by-nc) Spain 3.0 License

RESUMEN: A finales de los años noventa España comenzó a diseñar programas dirigidos al reclutamiento de trabajadores estacionales para el sector agrícola. En la década pasada, y coincidiendo con un período de intenso crecimiento económico, estos programas fueron aplicados en determinadas provincias españolas con el objetivo de promover formas de migración temporal y circular. La implantación de estos programas, en los que participan un amplio número de actores públicos y privados, supuso una excepcionalidad en la tradicionalmente reactiva política española de inmigración laboral. Estos programas dotaron, adicionalmente, de un estatuto legal anómalo a este tipo de trabajadores a través de la contención del acceso a permisos permanentes y la limitación del establecimiento. En este artículo se analiza el diseño y la implantación de este tipo de programas en el caso español, la implicación de diversos actores, así como su gestión concreta en el caso de las dos provincias donde estos programas han tenido mayor volumen y continuidad, Huelva en la región de Andalucía y Lérida, en Cataluña.

PALABRAS CLAVE: Programas de importación de trabajadores migrantes estacionales; circularidad migratoria inducida; inmigración laboral; agricultura; España. 


\section{INTRODUCTION}

During the 1990s, Spanish policy on labor migration regulation was designed and implemented with little state intervention. Faced with intense flows and inexperienced management, the migration policy that emerged was reactive and regarded managing labor migration as a secondary concern. The demand for workers during this period of sustained economic growth led to patterns in which immigrants entered the territory informally and were de facto incorporated into the labor market. The formal procedures in the 90s, based on annual worker quotas, failed due to the disparity between the real needs of the labor market and the size of those quotas, and administrative constrictions, specifically the slowness and lack of coordination among managing institutions.

The disparity between supply and demand and the lack of regulated mechanisms to recruit foreign workers created problems for some economic sectors, especially in those that are labor intensive and highly seasonal, such as agriculture. In the latter half of the $90 \mathrm{~s}$, the demands of the growers were somewhat reflected in the design of Spanish immigration policy, which promoted programs to contract seasonal foreign workers. When these programs were implemented at the start of the past decade, they became one of the few formal political mechanisms under state control that channeled foreign workers to the Spanish labor market.

By the middle of the past decade, the systems used to import seasonal foreign workers for the agriculture sector in Spain became highly formal and effective, despite their limited number. These programs promoted a mobility regime that was unique among Spanish migration regulations due to three aspects. First of all, the programs are established as joint management systems based on a demand agreed upon by a broad network of public and private actors at the local and regional level. Unlike in other countries, this is not a national program, but rather various micro-guest worker programs that are closely tied to local labor market needs. Secondly, this system preferentially recruits workers from countries that have signed bilateral agreements on immigration with Spain. Thirdly, a temporary migration regime has been designed through these programs that limits the possibility of immigrants settling permanently in the territory and promotes what we have defined as forms of induced circular migration, in reference to a type of circular migration encouraged from above.
The objective of this article is to describe and analyze the design and development of these programs in the Spanish case over the past decade. The analysis focuses on the middle of the past decade when the number of workers recruited under these programs reached its highest volume. The results presented are based on analysis of documentation and legislation related to these programs, as well as on information obtained during fieldwork carried out in 2012 and 2013. This fieldwork includes interviews conducted with representatives of national labor unions and growers' associations, public bodies of the national, regional and local administration, and social organizations that participate or supervise the implementation of these programs ${ }^{1}$. The text discusses the structural issues that led to this approach to managing labor immigration, as well as how it was articulated in legislation and policy. It also details how these programs function and discusses the characteristics that separate them from more general migration management procedures and succinctly presents the network of actors involved ${ }^{2}$. The text also looks at how these programs were implemented in the two Spanish provinces in which they had the greatest impact, Huelva and Lleida, and analyzes the effect of the economic crisis on their gradual discontinuation since 2009. One of the main conclusions reached from the analysis of the cases studied is that the implementation of this kind of program, which promotes forms of induced circular migration, has ended up producing spontaneous intra-European circular migration.

\section{GLOBAL AGRI-FOOD INDUSTRY AND “NEW” GUEST- WORKERS PROGRAMS}

Starting in the middle of the 1980s the intensive agricultural production of high value horticultural products has been restructured, transforming the economic and demographic dynamics of many rural communities. The agri-food industry's high level of modernization in terms of technology and production, as well as its focus on external markets and intensive use of workers, has converted the territories where they operate into areas which see very intense processes of capital and labor mobility (Goodman and Watts, 1994; McMichael, 1994; Martin, 2013; Ruhs, 2006). In these global agricultural "factories" labor relations must be highly flexible and production is ruled by the seasonal discontinuity of the crops and by the changing demands of the markets. In these agricultural communities, the national labor force has gradually been replaced by resident immigrant workers and also by immigrants who follow the seasonal agricul- 
tural circuit, temporarily settling during harvests. The presence of immigrant day workers during planting and harvesting campaigns has become one of the most significant aspects of the communities where agri-business is located.

Over the past few decades, these new agricultural landscapes have been considered ideal to implement seasonal foreign worker programs in North America and Europe. The "new" programs are tied to the concept of circular migration, a type of mobility which seeks to avoid the pitfalls of past programs by restricting how long the worker can stay in the territory, thereby providing an effective way to cover labor needs, while simultaneously fighting against the hiring of irregular immigrants. Circular migration is the element that differentiates the intentions of these new programs from those of earlier programs. Under this new approach, recruiting guest workers becomes a conditional and selective process in which controlled admission is combined with mandatory return.

This new design has substantial ramifications. First of all, it promotes a kind of flexible mobility that adapts to changing economic conditions and labor demands (López-Sala and Sánchez-Montijano, 2014; López-Sala and Godenau, 2015). Second, the temporary nature of their stay affects the ability of the migrants to obtain permanent legal status, as well as some social and labor rights (Basok and López-Sala, 2015). Finally, it entails the creation of a regime to regulate migration that operates within the territory (rather than at the borders), employing mechanisms to monitor the workers during their stay that determine if the workers are eligible to circulate in the future.

Growers feel that it was necessary to open the national labor market to meet their demands and improve their profitability. However, these programs have been heavily criticized by social organizations and trade unions. Trade unions suspect that these programs will worsen the working conditions of agricultural workers and promote competition between local and foreign workers (Holgate, 2011). Some argue that these programs might lead to internal civic stratification within immigrant communities, due to a regulation that promotes legal and contractual asymmetry among the foreign population (Carens, 2008). The position of the receiving states has been ambivalent. On the one hand, unmet labor demands are problematic for the economy and seasonal immigrant workers do not create added costs for the welfare state. On the other, mechanisms have been developed to ensure that these kinds of workers benefit from the same working conditions and labor rights as native workers during their stay, especially social security rights, minimum wage and legal protection. Local governments have seen these programs as a way to contain the settlement of immigrant populations and to minimize the potential effects that the presence of foreigners can have on the way of life and identity of these communities. As the workers channeled by these programs are under state control, the programs are considered the best option to avoid uncontrolled flows and the emergence of illegal settlements.

\section{SEASONAL MIGRANT WORKERS PROGRAMS IN SPA- NISH AGRICULTURE}

\section{A demand-driven regime}

The transformation of the Spanish agriculture system has had significant repercussions on its labor market, especially in the sector dedicated to producing fruit. This is a highly profitable market that is very dependent on technological innovations and the availability of workers. The poor working conditions in this sector and its instability, caused by climatic variations and the volatility of demand, the improved economic conditions in areas where this kind of agriculture has emerged and the low status of working in the fields has produced the gradual movement of the national active population toward other economic sectors.

Throughout the 90s, agri-businesses suffered recurring problems in finding enough workers for planting and harvesting some crops. For years the lack of native workers and maintenance of demand was covered by population moving from other Spanish provinces and Portugal and later, by immigrants who travelled the seasonal agriculture circuit, but who later left this sector when they managed to enter into other emergent sectors, such as construction, where they obtained better working conditions. The lack of regulation led to large numbers of people moving in from other parts of Spain, which was accompanied by problems caused by their concentrated presence over a short period of time, such as the lack of basic services and overcrowding. In the second half of the 90s the need for workers became a key factor in the continuity of the sector. Several political initiatives were launched with collaboration between public institutions and growers, aimed at regulating the mobility of the population that worked the seasonal circuit. Designing a policy specifically to contract foreign workers in their countries of origin was in large part a response to the demand of growers organizations and trade unions in 
the agricultural sector, as well as by local administrations who solicited institutional support to deal with the arrival of irregular immigrant workers integrated in the seasonal circuit.

Two traits were incorporated by these early political initiatives. First, they wanted to create a legal framework that would make it easier for diverse public and private institutions to collaborate in the management of migratory flows of seasonal workers. This kind of process, which incorporates mechanisms agreed upon by consensus, forms part of a tradition in the construction of Spanish migratory policy that dates back to the beginning of the 90s. Moreover, the decentralization of the Spanish political system requires various levels of government to be involved in putting this cooperation into practice and searching for consensus in decision making. Second, these initiatives were established as an ad-hoc system to complement the more general instruments used to manage labor migrations.

This kind of seasonal work was regulated through two legal agreements that were the starting point for the programs importing foreign seasonal workers for the agriculture sector. In 1997 the first Cooperation Framework Agreement to organize domestic migrations to meet temporary employment during agriculture campaigns was signed with the participation of the Ministry of Labor, the major trade unions, UGT and CCOO, the Spanish Federation of Municipalities and Provinces (FEMP) and the main growers organizations (COAG and ASAJA). The objective of this agreement, which had a local and territorial focus, was to meet labor demand in agricultural areas and to regulate worker mobility within Spanish territory. In order to achieve this goal, it established a system of institutional cooperation that allowed for adequate planning and organization of temporary work in agricultural campaigns and ensured the improvement of social and labor conditions for immigrant workers. Two years later, in 1999, an additional protocol was approved. This protocol developed procedures to present job offers through the Provincial Labor Commissions ${ }^{3}$.Through this protocol seasonal foreign workers were given the same labor and social rights as native workers, defined by the collective bargaining agreements of the sector. This agreement imposed certain obligations on growers participating in these programs: they were obliged to organize and pay for part of the worker's travel expenses, to provide housing and guarantee a minimum period of continuous activity.

\section{Selection, temporariness and rights}

Starting in 2001, these kinds of programs were put into action in various parts of Spain to complete the labor supply of resident foreign workers. They can be described as micro-guest worker programs for two reasons: their territorial fragmentation and limited volume. Their implementation was accompanied by specific conditions not applied to other kinds of nonseasonal workers. First, at the local level the provincial labor commissions establish an annual number of workers for agricultural campaigns that lack workers. These job offers are directed at workers residing outside of Spanish territory, offering contracts that could last up to 9 months in a one year period. Second, the immigration entering Spain through this mechanism is conceived as temporary, and explicitly requires the seasonal workers to return. They must sign a return commitment, which includes registering, after their return, in the Spanish consulate that previously had issued their work visa. Violating the terms of the agreement could later lead to denial of permit requests during a period of up to three years. However, fulfilling the return commitment on time qualifies the worker to be hired the following year, without having to go through the selection procedure again, if the employer asks for the same worker by name. This regulation has serious implications for the legal status of the migrants. The possibility of returning to work in agricultural campaigns in later years is conditioned not only by continuity of labor demand, but also by the worker's previous return and the willingness of the grower that had previously hired the worker to ask for them by name. The ways in which these workers can obtain a more stable legal status are extremely limited. Currently, in order to obtain a more stable work permit it is necessary for the worker to have participated in campaigns for several years and to receive a job offer by an employer in the sector. However, in practice the seasonal nature of this kind of work, coupled with the hesitance of growers to encourage the settlement of immigrants in these agricultural areas, has made it rare for workers to obtain a more permanent status.

In the third place, these programs establish preferential recruitment of workers from countries that have signed bilateral agreements on migration with Spain ${ }^{4}$. These agreements activate a system of selection and supervision controlled by the Spanish government that includes every stage of the migration process, starting in countries of origin and continuing throughout their stay in Spanish territory. This super- 
vision is often carried out jointly with local organizations $^{5}$ that have become intermediary bodies through specific agreements with national labor agencies in countries of origin.

Contracting seasonal workers through bilateral agreements involves the countries of origin and the creation of various mechanisms of bilateral cooperation: a) first, the country of origin has to create a mechanism to receive generic job offers and search for and select adequate candidates for those jobs; b) second, a body must be created from the governments of both countries (bi-national coordination committee) that functions as a selection commission in which representatives of Spanish companies recruiting workers can also participate; and c) finally, a set of procedural agreements must be put in place to expedite the documentation of selected workers and their move to Spain.

Throughout the last decade, the implementation of these programs and the process of selecting workers have been influenced by the preferences of the growers. Their obligation to cover part of the travel costs of the workers has favored selection from nearby countries, at first from Eastern Europe, such as Poland, Ro- mania and Bulgaria, and later from Morocco ${ }^{6}$. Research, including our own field work, has shown that in the Andalusian province of Huelva women were preferentially recruited, and in second place, workers with experience in the agricultural sector, a factor that the growers claim favors their incorporation into this type of work (Gordo, 2009a; Gualda, 2012; Moreno-Nieto, 2012; Mannon et al., 2012; Hellio, 2014). The effectiveness of the institutional agencies taking part in selection processes in the different countries of origin has also been a factor in deciding where recruitment programs were consolidated. After initial experiences, bilateral cooperation was reinforced in certain countries, while the program was discarded in others. Cooperation has been especially effective in Romania, Poland, Colombia and Morocco. In contrast, small pilot programs tested in Senegal and Ecuador were not repeated.

Finally, regarding the acknowledgement of rights for these kinds of workers, these programs guarantee equal labor and social rights for migrants during their work stay in Spain, including healthcare, but their temporary status limits other rights, such as the ability to obtain a work permit in another sector, as well as the right to receive unemployment benefits or to take advantage of family reunification.

\section{Seasonal Migrant Workers Programs in the Spanish Agriculture}

Design and implementation have been shaped by:

- The decentralized political system.

- A consensual policymaking "tradition" in Spanish migration policy. Representatives of trade unions, business organizations, NGOs, migrant organizations, etc., agree upon the policy.

- Negotiation, through bilateral agreements with individual labor-exporting countries.

Worker Selection and bilateral management

- Migrants are allowed to stay for up to 9 months a year to fill labor shortages on farms during peak periods of planting and harvesting of specific farm commodities.

- Workers from countries that have signed bilateral agreements with Spain were given preference in obtaining seasonal work permits.

- Employers choose countries from which to recruit workers (Morocco, Poland, Romania, Bulgaria and Colombia).

- Experience in agriculture sector as a key element in the selection process.

- The program is run jointly with the governments of countries of origin (bi-national commission and pre-selection process). Circularity

- Compulsory return at the end of the contract. Returning workers have to check in at the Spanish consulates in countries of origin. Hiring preference in subsequent years.

Rights

- While under contract, guest workers are entitled to most labor and social rights including health care and social security benefits.

- As part of bilateral agreements, growers must organize worker transportation to and from Spain and pay for a part of the cost. 


\section{The rationales driving implementation}

As mentioned earlier, the rationale behind developing measures to hire workers in their countries of origin responds to a combination of structural conditions linked to demand for workers and the conditions for regulating international mobility to Spain. Therefore, any analysis of this policy must consider the underlying market forces and government rationales ${ }^{7}$. The market seeks to funnel workers to sectors whose profitability is largely tied to having sufficient workers, but that are suffering shortages. Strictly speaking, this is a key factor in the design of a policy based on business interests, in terms of the number and profile of the workers. At the same time, the Spanish government prioritizes the formal regulation of migration flows through the creation of mechanisms to recruit workers and channel them to the sectors where they are needed, while also fighting against unauthorized immigration, limiting settlement and maintaining internal control over these kinds of workers. These two aspects are particularly complex in the Spanish case due to the country's "multi-level governance" and the fact that authorities on a regional level have a great deal of say in the decision making process. Moreover, there is a broad confluence of interests and actors involved in designing immigration policy.

This broad network of actors participates both in the design and implementation of the policy. The national and regional administrations decide on annual quotas and design mechanisms for selecting workers. Furthermore, in response to the demand of growers, the administrations have also created more efficient and less bureaucratic hiring procedures for these programs. In addition to participating in setting the annual quotas, trade unions supervise the working conditions of the hired workers and the housing provided by the growers. This participation has helped convince them to support these programs, which also have cooperation agreements with trade unions in countries of origin, such as Poland and Romania.

The local administrations have also had a significant role in assisting seasonal workers to settle in their areas temporarily. There have been two main actions in this regard. First of all, in many cases programs have been developed to welcome the seasonal workers, including cultural activities and educational opportunities, especially to learn Spanish. These services have partially been provided through agreements with NGOs. Secondly, some city councils have provided municipal installations to house seasonal workers and have established municipal information offices to help migrants obtain access to healthcare and social services during their work stay in Spain.

Since the middle of the last decade the Spanish Ministry of Labor has financed the entities involved in managing these flows, through a system of co-funding and subsidy from the central government. This funding, which has benefitted city councils, growers and union organizations and NGOs, has had three objectives: to cover the transportation costs involved in importing workers from countries of origin, to fund part of their housing and to supervise the working conditions of the workers. In some provinces, the growers have delegated their representation in the selection process and in providing housing to private entities, such as growers organizations and semi-public foundations.

An initial comparative analysis of Spanish agricultural hiring experiences shows certain patterns that we can highlight as preliminary conclusions. In general terms, hiring in countries of origin has been a minority mechanism in the overall process of incorporating foreign workers into Spanish agriculture. In general it has been a "narrow" channel subject to fluctuations in economic dynamics and largely determined on a local level.

The demand for foreign workers has been particularly intense in sectors abandoned by the native population and resident foreign workers, caused in part by the low salaries imposed by some collective bargaining agreements in certain agricultural branches. In the opinion of the majority of agricultural trade unions, improving the labor conditions of the collective bargaining agreements would limit the demand for foreign workers and promote employment of the resident population.

In addition, due to the cost paid by the growers to import and house the workers, hiring in countries of origin is only profitable for campaigns of medium duration (4-6 months). This explains why throughout the past decade this method of hiring was important in provinces such as Lleida and Huelva (in perishable fruit campaigns), while it had little impact in other Spanish provinces that have much shorter campaigns, (such as the olive, garlic or grape campaigns). Variations in local production levels also play a decisive role in explaining why growers have or have not used these programs. In other important Spanish agricultural regions, such as Murcia, Valencia, and Almeria, campaigns occur one after another throughout the year and activity in agriculture is combined with work in other sectors, such as tourism and hospitality. This permanent demand for workers has led 
to an immigrant population settling in those areas, putting the brakes on programs based on temporarily importing workers.

Growers have become particularly active actors in the implementation of these programs in the case of crops with the greatest economic growth and profitability, such as strawberries (Sánchez-Montijano and Fáundez García, 2011). Finally, the success of some of these programs has also depended on an effective collaboration between the public sector, civil society, growers organizations and the institutions involved in this process in countries of origin.

\section{THE IMPLEMENTATION OF SEASONAL MIGRANT WORKER PROGRAMS IN SPANISH AGRICULTURE: THE CASES OF HUELVA AND LLEIDA}

Huelva is the Spanish province where this kind of program has had the most widespread implementation, both in terms of continuity and number of work$\mathrm{ers}^{8}$. Huelva is located on the southwestern coast of Spain, in the region of Andalusia. Since the 1980s it has seen a dramatic increase in the use of plasticulture (the use of plastic greenhouses) for the heavy production of highly profitable horticultural products exported to international markets, particularly strawberries and other red fruits. In just over three decades, this province has become the main strawberry producer in Europe and the second largest in the world, behind California. This activity has had serious repercussions on the economic and labor dynamics of the province. Each year the more than six thousand hectares of land dedicated to strawberries produce between 240,000 and 270,000 tons, $80 \%$ of which is exported, producing profits of between 250 and 300 million euros per campaign (Junta de Andalucía [Regional Government of Andalusia], 2012a; Junta de Andalucía [Regional Government of Andalusia], 2012b; Junta de Andalucía [Regional Government of Andalusia], 2014 ). This is why strawberry production in this Andalusian province is sometimes referred to as Red Gold.

The effect of the expansion of strawberry growing on local employment has been highly significant. Between the end of February and the middle of June, between 50,000 and 80,000 people can be employed to pick and package fruit, generating just over four million days of work (Jurado, 2009; Márquez and Felicidades, 2012). However strawberries are highly perishable and extremely dependent on meteorological conditions. To maintain effective production capabilities requires effective and flexible mechanisms to deal with the uncertainties of the weather. This is why having a large work force available at the right time is vital to its production and commercialization. In a "just in time" system, this availability is often crucial to meet the demands of the large distribution circuits and to compete with production from Morocco and other producers in Northern Africa (Marañon-Abreu, Gualda and Valerdi, 2011).

The expansion of strawberry production in Huelva has generated a growing demand for workers in this sector, which is currently a strong economic motor at the provincial and local levels. In the 90s this demand was covered by day workers who travelled to Huelva from other parts of Andalusia and later by Moroccan and Algerian workers who strung together campaigns in different provinces in southern and eastern Spain. However, since the middle of the 90s the local population has increasingly abandoned this sector, especially the harvest, during which working conditions are more difficult. The increased level of wealth in the area and the poor working conditions ${ }^{9}$ made the strawberry fields an unattractive destination for the local population and resident immigrants.

The programs for recruiting foreign seasonal workers began to be implemented in Huelva in 2001. After that campaign the number of workers hired abroad grew exponentially, nearing 40,000 by 2008 (Gordo, 2009a; Gualda, 2012; Márquez et al., 2013; Gordo, Márquez and Jurado, 2013; Márquez, 2015), although it has decreased substantially since then. However, over time the profile of the foreign workers and the countries in which recruitment was carried out for the program went through significant changes, following the preferences of the growers and the opportunities offered by the labor migration agreements carried out by the Spanish government. In this sense, there is consensus among the actors that have been interviewed in the field work that, unlike Lleida, the strawberry growers in Huelva have tried out this program in various countries, with the goal of testing the effectiveness and skill of workers of different nationalities in the campaigns. The preferences of the growers have extended to other characteristics of the workers. In general terms, women have been favored during recruitment ${ }^{10}$ and since the middle of the past decade workers from rural areas with previous experience in the agricultural sector were preferentially recruited. Between 2002 and 2005 the majority of the agricultural workers recruited to work in Huelva through these programs came from Poland and Romania and after 2006, although flows from Eastern Europe were maintained, recruitment increased in Morocco. Over 
the years, the growers have mostly switched from generic job offers to recruiting workers they had employed in earlier campaigns by name. In practice, this process has produced high levels of circular migration among those recruited previously in various countries and also led to recurrent hiring based on trust and the establishment of prior personal networks. The negative side of this process is that these kinds of programs have led to a mobility regime that in practice makes workers highly dependent on a certain employer.

Supervision of the working conditions of workers recruited through these programs was carried out through visits to the farms by trade union organizations and job inspectors. The government has also checked if the workers fulfilled their commitment to return to their countries of origin. According to estimates made by the administrations and union representatives interviewed, during the first campaigns approximately $80 \%$ of the workers hired returned to their countries of origin. Therefore, since 2005 a special procedure was put in place, supervised by the Government Delegate's Office and the Guardia Civil, in order to register arrivals and departures at the farms themselves. According to interviews with institutional and union representatives, this process has guaranteed that practically all workers returned to their countries.

Since the 2009 campaign there has been a continuous decrease in hiring from countries of origin in Huelva, reaching its lowest point in the most recent campaigns, with barely a few hundreds of workers contracted for harvest work, despite the fact that demand has remained high in the still growing sector. There are various factors involved in this change. First of all, after Bulgaria, Poland and Romania entered the European Union, many of the workers that had been contracted previously through these programs now have freedom to circulate throughout the EU and they have created personal networks with growers that hired them temporarily during past campaigns. In the Spanish case, the induced circularity promoted by these programs has ended up consolidating in forms of spontaneous intra European circularity, mainly in the case of Romanian workers, when the obstacles to immigration imposed by policies were eliminated.

In the second place, the economic crisis has had a heavy impact on local employment and how this policy is designed. Since 2010 these programs are only open to non-EU workers who have previously participated in the programs, during past annual campaigns. This regulation, therefore, ensures that all foreign workers participating in the program today are workers known in the terminology of the local administrations as "repeaters". The economic crisis has also produced a gradual decrease in the size of the annual quota of workers set by the provincial labor commission (López-Sala, 2013; López-Sala and Sánchez-Montijano, 2014). Moreover, hiring in countries of origin has been reduced to only harvest work and is no longer used for planting campaigns or packaging. And in the past year the government has pressured the growers to prioritize hiring local workers. This situation has created a great deal of tension. The economic crisis may lead to unemployed native workers returning to the sector, along with resident immigrant workers who have lost their jobs in other sectors, such as construction and hotel services. The central and local governments, the trade unions and the growers themselves are under heavy "social pressure" to constrain the arrival of foreign workers from abroad, but growers are quite reticent to comply, since they do not believe that local workers will be sufficient to meet their needs during campaigns, even in the current economic crisis context.

The fruit tree sector in the Catalonian province of Lleida shares many of the traits mentioned previously in the Huelva case: the development of a technology intensive agriculture with the goal of international commercialization and the use of salaried immigrant farm workers.

The province of Lleida, specifically the counties of Segrià, Les Garrigues, La Noguera, l'Urgell and Plá d l'Urgell, is one of the largest fresh fruit producers in Europe, known especially for apple, pear, peach, plum and nectarine production. Per year, around 200,000 tons of pears, 230,000 tons of nectarines and peaches and just over 160,000 tons of apples are harvested and sold on the domestic market or exported. Catalonia accounts for nearly $70 \%$ of all Spanish exports of these fruits to Germany, France, Italy, Holland and Belgium and increasingly to Eastern European countries, such as Russia and Poland (Generalitat de Catalunya [Regional Government of Catalonia], 2012; Generalitat de Catalunya [Regional Government of Catalonia], 2014).

Although this sector received an important boost in the 1980 s by the professionalization of traditional family farms, its competitiveness within the European market was only consolidated in the second half of the 1990s through a strategy that combined technological innovation, diversification of the variety of fruits and international commercialization. As occurred in the case of strawberry production in Huelva, 
one of the traits of this kind of agri-business has been its enormous dependency on the availability of workers, especially during harvest campaigns. The difficulties involved in applying technological innovations to fruit tree harvesting systems makes it necessary to have between 8,000 and 9,000 workers available for manual labor during harvest campaigns.

Just as in Huelva, for years these needs were covered by local workers, students who worked in the sector seasonally and by crews arriving from other parts of Spain, especially Extremadura and Andalusia. This work force was, however, highly volatile, quickly abandoning the campaigns if a better job opportunity arose in other sectors, a situation that was exacerbated in the second half of the 90s when the economic boom increased the wealth and income levels in the country. Just as in Huelva, the enormous impact of this profitable agri-business on the provincial economy ended up increasing the "level of what was acceptable" for the local population (Cachón, 2009) and local workers were replaced by foreign labor. The arrival of workers from the Magreb in the 1990s partially met the demand, although many of them were irregular immigrants, which highlighted the need for formal alternatives to channel workers to the sector, which as it continued to grow would need more workers.

The seasonal workers program was implemented in 2001, the same time as in Huelva, but it was smaller in volume. Between 2002 and 2008 the number of annual contracts was just over a few thousand a year, with 2007 registering the largest volume, with over 6,000 workers hired. Since 2009 these numbers don't reach 1,000 people a year (Díaz et al., 2013). As in Huelva, the model implemented in Lleida has garnered a great deal of international interest for its design linking circular migration and development in communities of origin, especially through the program implemented by the organization of agricultural growers Unió de Pagesos (Zapata Barrero, Fáundez and Sánchez-Montijano, 2009; Sánchez-Montijano and Faúndez García, 2011; Mejia, 2008). The development and implementation of this program has followed the legal and policy guidelines developed on the national level, but it has also received additional resources from the regional Catalonian administration, specifically the creation of the Labor Intermediation and Training Service (SILO) within the Catalonia Occupation Service (SOC) directed at Catalonian growers to help hire workers in their countries of origin. The assistance provided by this intermediation service extends to all facets of the process, from the selection of workers, to joint man- agement with labor agencies in the countries of origin $^{11}$, processing the paperwork, implementing what are known as "first housing modules"12 and the registration of their return ${ }^{13}$

Hiring for the program in Lérida was carried out in some Eastern European countries, such as Poland and Romania, in Morocco and Colombia and the workers selected were more diverse in terms of gender and area of origin, including workers from rural and urban areas.

In the case of Lleida, some growers organizations have played a major role in putting these programs into practice. One of them was Unió de Pagesos, an association of agricultural growers businessmen which includes $70 \%$ of the agriculture businessmen in Catalonia. The goals of this organization changed from merely lobbying for the implementation of a program to import seasonal workers in this area of Catalonia at the end of the 90s, to providing intermediation when it became a unique placement agency, managing housing and formally providing services for growers and migrants.

Just like in the Huelva case, the economic crisis has had a severe impact on the implementation of the program in this Catalonian province, which has seen a significant and progressive decrease in numbers. Since 2009 part of the labor demand has been filled by workers from Eastern Europe who are not subject to limits on their movement. In addition, since 2010, as in the case of Huelva, the priority has been given to hiring unemployed local workers and resident immigrants, in Lleida and other Catalonian provinces, which seems to have promoted interregional mobility.

\section{CONCLUSIONS}

In Spain there is no general program for seasonal workers in the agriculture sector (SWAP) like those in other European and North American countries. On the contrary, only local programs in several provinces and crops campaigns have been designed and implemented, some of them with great volume and continuity. These programs have been designed and applied at the local level within the framework of national regulatory legal systems and the National Framework Agreement on seasonal workers. This agreement created a formal channel for consensual, flexible decision making involving several public and private actors that was broadly tied to local economic and employment dynamics. 
Considering the nature of Spanish migration policy as a whole over the past decade, it can be said that these programs were designed to be innovative and active instruments within the traditionally reactive Spanish labor immigration policy. Through these programs the state tried to: a) create a proper scenario (legal and administrative) to guarantee labor supply for agriculture; b) confront low institutional responsiveness to economic and labor market fluctuations; and c) create an alternative to irregular migration and permanent settlement. However, these programs also introduced a unique mobility regime within Spanish migration regulation. First of all, these programs promoted forms of induced circularity, which as we have seen ended up encouraging spontaneous inter-European circular mobility after EU enlargement. Second, they imposed a specific migration regime for seasonal agricultural workers that can be considered anomalous within the Spanish legal system and which creates a category of migrants subject to heavy restrictions. In the case of these workers the restrictions are mainly derived from the mandatory commitment to return to their countries of origin and a limitation to their access to more stable or permanent migratory statuses.

\section{NOTES}

[1] Fieldwork was carried out in Huelva and Lleida, the two Spanish provinces which had the greatest number of guest workers recruited through these programs in agricultural campaigns. Interviews were also carried out with political authorities and experts in the central administration and regional governments of Madrid and Catalonia. This fieldwork was conducted in the framework of the CIRCULAR Project (grant number CSO2011-27115) funded by the Spanish National Research Program.

[2] Interviews were conducted by the author and Inara Stürckow. Grateful thanks to all the individuals who gave interviews about their experiences and expertise in the design and implementation of these programs. I want to thank Estrella Gualda for her helpful comments and support in the fieldwork conducted in the province of Huelva. I also would like to thank the anonymous reviewers for their valuable comments and suggestions.

[3] Provincial labor commissions determine the labor needs for the province in various economic sectors. These commissions include the participation of provincial representatives of the Ministry of Labor and representatives of the most important local business organizations and trade unions.

\section{REFERENCES}

Basok, T. and López-Sala, A. (2015). Rights and Restrictions: Temporary Agricultural Migrants and Trade Unions' Activism in Canada and Spain. Journal of Migration and Integration, 16, pp. 1-17. http://dx.doi.org/10.1007/s12134-0150465-6
[4] Since 2001 Spain has signed labor migration agreements with European, African and Latin American countries: Colombia (2001), Ecuador (2001), Dominican Republic (2001), Morocco (2001), Romania (2002), Poland (2002), Bulgaria (2003), Mauritania (2007), and Ukraine (2009).

[5] This is the case of Unió de Pagesos (UP) in the Catalonian province of Lleida or Fundación para los Trabajadores Extranjeros de Huelva (FUTEH) in the Andalusian province of Huelva.

[6] The main exception is the case of Colombia, where workers were recruited for fruit harvesting campaigns in the province of Lleida.

[7] As indicated by Zapata, Faúndez and Sánchez Montijano, this plural institutional framework clearly reflects the twofold objective of liberalization and regulation (Zapata Barrero, Faúndez and Sánchez-Montijano, 2009).

[8] In several international reports it is also regarded as a model promoting circular migration (see Newland, Agunias and Terrazas, 2008; Martin, 2011; Plewa 2013).

[9] Huelva has one of the worse agricultural bargaining agreements in Andalusia and Spain. The cost of an hour of work is 38

Cachón, L. (2009). La España inmigrante. Marco discriminatorio, mercado de trabajo y políticas de integración. Barcelona: Anthropos.

Carens, J. (2008). Live-in Domestics, Seasonal workers, Foreign Students, and other hard to locate on the Map of euros, compared to 42 euros for the olive campaign, where the conditions are more inconsistent, or the grape campaign where an hour of work is paid at 70 euros.

[10] Interviewed institutional, union and growers representatives sustain that, just as other research carried out in the province concluded, that the growers generally preferred to hire women, which has feminized and "invisibilized" local agricultural work (Gualda, 2008, 2009, 2012; Moreno-Nieto, 2012; Reigada, 2012; Miedes Ugarte and Redondo Toronjo, 2007).

[11]SILO had offices in Poland until 2008 and in Colombia and Morocco until 2010. They established work agreements with ANAPEC (Job and Training Service of Morocco) and SENA (Job and Training Service in Colombia).

[12]These modules consist in training sessions directed at recently arrived workers with the goal of introducing them to Catalonia and its labor laws.

[13]The work carried out by SILO to supervise returns, which involved gathering documentation in the ports and airports, made it unnecessary for workers in these campaigns to register their returns at the Spanish consulates in their countries of origin.

Democracy. Journal of Political Philosophy, 16, 4, pp. 419-445. http://dx.doi. org/10.1111/j.1467-9760.2008.00314.x

Díaz, J., Márquez, J. A., Jurado, J. M. and Gordo, M. (2013). El principal destino agrícola de los inmigrantes extranjeros en Cataluña: la fruticultura leridana. In 
Camacho, J. A. and Jiménez, Y. (eds.). Desarrollo Regional Sostenible en tiempos de crisis. Granada: Universidad de Granada, pp. 799-819.

Generalitat de Catalunya (2012). Informe anual 2012. Barcelona: Departament d'Agricultura, Ramaderia, Pesca, Alimentació i Medi Natural.

Generalitat de Catalunya (2014). Informe anual 2013. Barcelona: Departament d'Agricultura, Ramaderia, Pesca, Alimentació i Medi Natural.

Goodman, D. and Watts, M. J. (1994). Reconfiguring the rural or fording the divide? Capitalist restructuring and the global agrofood. Journal of Peasant Studies, 22, 1, pp. 1-49. http://dx.doi. org/10.1080/03066159408438565

Gordo, M. (2009a). La implantación de los contratos en origen en las campañas agrícolas de temporada. El liderazgo de la provincia onubense. In Gordo, M. and Felicidades, J. (eds.). Explorando los contratos en origen en los campos españoles. Huelva: Universidad de Huelva, pp. 119-143.

Gordo, M. (2009b). Y las polacas habitaron entre nosotros. Preferencia de los agricultores onubenses por las temporeras de Polonia y su situación actual. In Gordo, M. and Felicidades, J. (eds.) Explorando los contratos en origen en los campos españoles. Huelva: Universidad de Huelva, pp. 155-184

Gordo, M., Márquez, J. A. and Jurado, J. M. (2013). La Fundación para los Trabajadores Extranjeros en Huelva (FUTEH) y la gestión colectiva de los contratos en origen en Marruecos. In AGIR (Revista Interdisciplinar de Ciencias Sociais e Humanas), 1, 1, pp. 160-195.

Gualda, E. (2008). De polacas a senegalesas: contratos en origen, sustitución étnica y segmentación del mercado agrícola onubense. Panorámica Social, 8, pp. 71-84.

Gualda, E. (2009). Mujeres inmigrantes en la agricultura. Dinámicas de invisibilidad y visibilidad. In Moyano, E. (ed.). Agricultura familiar en España 2009. Madrid: Fundación de Estudios Rurales, pp. 228-233.

Gualda, E. (2012). Migración circular en tiempos de crisis. Mujeres de Europa del Este y africanas en la agricultura de Huelva. Papers, 97, 3, pp. 613-640.
Hellio, E. (2014). We don't have women in boxes. Channeling seasonal mobility of female farmworkers between Morocco and Andalusia. In Gettel, J. and Sippel, R. (eds.). Seasonal Workers in Mediterranean Agriculture: The Social Costs of Eating Fresh. New York: Routledge, pp. 141-155.

Holgate, J. (2011), Temporary Migrant Workers and Labor Organization. Working USA. The Journal of Labor and Society, 14, 2, pp. 191-199. http://dx.doi. org/10.1111/j.1743-4580.2011.00332.x

Junta de Andalucía. (2012 a). Estadísticas Agrarias, 2012. Sevilla.

Junta de Andalucía. Observatorio de precios y mercados (2012b). Evaluación de la campaña 2011/2012 de fresa y frambuesa en la provincia de Huelva. Consejería de Agricultura, Pesca y Medio Ambiente.

Junta de Andalucía. Observatorio de precios y mercados (2014). Campaña de la fresa 2013/2014. Consejería de Agricultura, Pesca y Medio Ambiente.

Jurado, J. M. (2009). Los nuevos paisajes de la agricultura en el litoral onubense. In Gordo, M. and Felicidades, J. (eds.). Explorando los contratos en origen en los campos españoles. Huelva: Universidad de Huelva, pp. 67-92.

López-Sala, A. (2013). Managing Uncertainty: Immigration Policies in Spain during Economic Recession (2008-2011). Migraciones Internacionales, 7, 2, pp. 39-69.

López-Sala, A. and Sánchez-Montijano, E. (2014). Contratación en origen de trabajadores latinoamericanos en España: una gestión basada en la flexibilidad. Revista CIDOB d'Afers Internacionals, 106-107, pp.193-213.

López-Sala, A. and Godenau, D. (2015). En torno a la Circularidad Migratoria: Aproximaciones conceptuales, Dimensiones teóricas y Práctica Política. Migraciones, 38.

Mannon, S., Petrzelka, S., Glass, C. and Radel, C. (2012). Keeping Them in Their Place: Migrant Women Workers in Spain's Strawberry Industry, International Journal of Sociology of Agriculture and Food, 19, 1, pp. 83-101.

Marañón-Abreu, R., Gualda, E. and Valerdi, R. (2011). The dynamics of circular migration in Southern Spain: An example of social innovation. Massachusetts Institute of Technology.
Márquez, J. A. (2015) (ed.). Más allá de la competencia agrícola hispano-marroquí. La gestión colectiva de los contratos en origen. Huelva: Universidad de Huelva.

Márquez, J. A. and Felicidades, J. (2012). Estructuras productivas del campo en la provincia de Huelva. In El Sector Agrario en la provincia de Huelva 2011-2012. Huelva: Fundación Caja Rural Sur, pp. 19-30.

Márquez, J. A., Gordo, M., Felicidades, J. and Díaz, J. (2013). Evolución de los contingentes de trabajadores extranjeros en España (1993- 2011): las actividades agrícolas. In Camacho, J. A. and Jiménez, Y. (eds.) Desarrollo Regional Sostenible en tiempos de crisis. Granada: Universidad de Granada, pp. 757-780.

Martin, P. (2008). Temporary Worker Programs: US and Global Experiences. [On line]. Available from http://www.metropolis.net/policypriority/migration seminar/PhilipMartinsPaper_e.pdf

Martin, P. (2011). International Labour Migration. The numbers-rights dilemma. In Koslowski, R. (ed.) Global Mobility Regimes. London: Palgrave, pp. 201-218. http://dx.doi. org/10.1057/9781137001948.0019

Martin, P. (2013). Immigration and Farm Labor: Policy Options and Consequences. American Journal of Agricultural Economics, 95, 2, pp. 470-475. http:// dx.doi.org/10.1093/ajae/aas089

McMichael, P. (1994). The global restructuring of agro-food systems. Ithaca: Cornell University Press.

Mejia, W. (2008), Working Model Findings Relative to Recruitment in Colombia of Workers for Temporary and Circular Migration by the Farmers Union of Catalonia: View from the Workers' Community of Origin. Pereira, Colombia: Universidad Tecnológica de Pereira.

Miedes Ugarte, B. and Redondo Toronjo, D. (2007). Trabajadoras extranjeras en los campos freseros. De la necesidad a la invisibilidad. Trabajo. Revista de la Asociación Estatal de Centros Universitarios de Relaciones Laborales y Ciencias del Trabajo, 20, pp. 183-205.

Moreno-Nieto, J. (2012). Movilidad transnacional, trabajo y género: temporeras marroquíes en la agricultura onubense. Política y Sociedad, 49, 1. pp. 103-122. http://dx.doi.org/10.5209/ rev_POSO.2012.v49.n1.36525 
Newland, K., Agunias, R. and Terrazas, A. (2008): Learning by doing. Experiences of Circular migration. Washington: Migration Policy Institute.

Plewa, P. (2009). Administration of Seasonal Foreign Worker Admissions to Huelva's Strawberry Agriculture. Preliminary draft of the presentation for the Immigration Reform: Implications for Farmers, Farm Workers, and Communities. Washington D.C., USA, May 21-22, 2009.

Plewa, P. (2013). The politics of Seasonal Labour Migration in Switzerland, France and Spain. International Migration, 51, 6, pp, 101-117. http://dx.doi. org/10.1111/imig.12134
Reigada, A. (2012), Más allá del discurso sobre la inmigración ordenada: contratación en origen y feminización del trabajo en el cultivo de la fresa en Andalucía. Política y Sociedad, 49, 1, pp. 103-122. http://dx.doi.org/10.5209/ rev_poso.2012.v49.n1.36524

Ruhs, M. (2006). The potential of temporary migration programmes in future international migration policy. International Labour Review, 145, 1-2, pp. 8-36. http://dx.doi. org/10.1111/j.1564-913x.2006.tb00008.x

Sánchez-Montijano, E. and Faúndez García, R. (2011). Migración laboral, temporal y circular y codesarrollo: estudio de caso de una articulación posible. Migraciones, 30, pp. 43-70.
Zapata Barrero, R., Fáundez, R. and Sánchez-Montijano, E. (2009). Migración laboral, temporal y circular (MLTC) de trabajadores entre Colombia y España. Un modelo a consolidar y replicar. Universitat Pompeu Fabra.

Zapata Barrero, R., Faúndez García, R. and Sánchez-Montijano, E. (2012). Circular Temporary Labour Migration: Reassessing Established Public Policies. International Journal of Population Research, 2012. http://dx.doi. org/10.1155/2012/498158 